S. Debogović, I. A. Nola*

\title{
PROFESIONALNI STRES I SINDROM IZGARANJA U DJELATNIKA INTENZIVNE PSIHIJATRIJSKE SKRBI I HITNE MEDICINE
}

UDK 159.944.4:616.89-089.98

PRIMLJENO: 8.1.2020.

PRIHVAĆENO: 31.8 .2020

Ovo djelo je dano na korištenje pod Creative Commons Attribution 4.0 International License

SAŽETAK: Posljednjih desetljeća puno se istražuje i govori o stresu na radnom mjestu koji je povezan s fizičkim, psihičkim ili socijalnim odgovorom, tj. disfunkcijom koja proizlazi iz osjećaja osobe da ne može ispuniti sve što se od nje očekuje, a može ga uzrokovati niz različitih čimbenika kao što su količina rada, organizacija posla, loša komunikacija, radno okruženje i slično. Sindrom izgaranja nastaje kao posljedica prisutnosti više stresora na radnom mjestu te dugotrajne izloženosti istima. Cilj ovog rada bio je istražiti prisutnost $i$ intenzitet profesionalnog stresa i sindroma izgaranja kod djelatnika intenzivne psihijatrijske skrbi i hitne medicine. Također, istraživani su čimbenici psihofizioloških napora povezanih s većim intenzitetom stresa u ispitanika te čimbenici povezani sa sindromom izgaranja. $U$ istraživanje bilo je uključeno 63 djelatnika intenzivne psihijatrijske skrbi Klinike za psihijatriju Vrapče i 63 djelatnika Nastavnog zavoda za hitnu medicinu Grada Zagreba. Korištena su tri standardizirana upitnika za samoprocjenu. Rezultati analize stresa na radnom mjestu kao značajnu izdvajaju kategoriju stresora "Organizacija radnog mjesta i financijska pitanja". U toj kategoriji $70 \%$ (N=88) od ukupnog broja ispitanika smatra da je stresor pod nazivom „Preopterećenost poslom" dominantan izvor stresa $(P=0,004)$. Procjena psihofizioloških napora pokazuje statistički značajnu razliku u kategorijama "Pritisak na poslu" $(P=0,001) i$ "Stres uzrokovan premalim radnim opterećenjem" ( $P=0,004)$. Pri procjeni sindroma izgaranja $31,7 \%(\mathrm{~N}=40)$ ispitanika ne pokazuje prisutnost sindroma izgaranja. Početno izgaranje uočeno je u 42,1\% (N=53) ispitanika, a visok stupanj izgaranja u 26,2\% (N=33) ispitanika. Rezultati dobiveni u ovom istraživanju ukazuju na potrebu provedbe programa sustavne prevencije i pomoći kod profesionalnog stresa i sindroma izgaranja te prepoznavanje specifičnih stresora za pojedinu ustanovu.

Ključne riječi: hitna medicina, intenzivna psihijatrijska skrb, medicinski djelatnici, profesionalni stres, sindrom izgaranja

\section{UVOD}

Stres predstavlja način na koji se mentalno, fizički i emocionalno reagira na različita stanja promjene i zahtjeve u ljudskom životu. Najčešće prihvaćena definicija stresa definira stres kao stanje ili osjećaj u kojem se nalazi određena osoba

*Siniša Debogović, mag. med. techn., (sinisa.debogovic@gmail. com), Klinika za psihijatriju Vrapče, Zavod za dijagnostiku i intenzivno liječenje, Jedinica hitne i prijamne službe, osoba za kontakt: izv. prof. dr. sc. Iskra Alexandra Nola, (iskra.nola@snz.hr), Medicinsk fakultet Sveučilišta u Zagrebu, Škola narodnog zdravlja "Andrija Štampar", Katedra za zdravstvenu ekologiju i medicinu rada i sporta, Rockefellerova 4, 10000 Zagreb. kada smatra da zahtjevi u njezinom životu premašuju osobna i društvena sredstva koja ta osoba ima na raspolaganju. Drugim riječima, stres označava događaj u životu čovjeka koji je definiran svojim intenzitetom i činjenicom da osobu onesposobljava za primjereni odgovor, ali ujedno izaziva i trajne poremećaje s patogenim učincima na psihičku organizaciju (Horowitz, 1978.). Važno je razlikovati vodi li reakcija na stres ka boljoj prilagodbi (adaptaciji) organizma ili pak u pogrešnu prilagodbu (maladaptaciju) i bolest. U oba slučaja dolazi do promjena u mozgu, tjelesnim funkcijama, raspoloženju i ponašanju. 
Stres je izrazito rizičan čimbenik za ljudsko zdravlje, uzročnik je niza psihičkih i tjelesnih bolesti i poremećaja, negativno utječe na profesionalno funkcioniranje i dovodi do pada kvalitete života. Može biti izazvan vanjskim podražajima poput umora, bolesti, fizičkim ozljedama i slično ili jakim emocionalnim doživljajem poput tjeskobe. Fiziološki stres je prirodni mehanizam koji organizam dovodi u stanje prikladno za obranu ili bijeg. Sam naziv stres ima podrijetlo iz srednjovjekovnog engleskog (engl. stress - napor, nevolja, ograničenje). Korišten je kao pojam već u 14. stoljeću kao oznaka patnje, muke, neprilike, tegobe, nesreće ili tuge (Lumsden, 1981.).

Osobe koje rade u sustavu zdravstvene zaštite svakodnevno su izložene djelovanju brojnih stresora na radnom mjestu, poglavito kad je riječ o zdravstvenim djelatnicima zaposlenima u hitnoj medicinskoj pomoći i intenzivnim bolničkim odjelima. Rizik rada na terenu i s akutno oboljelim pacijentima, smjenski i noćni rad, odgovornost pri donošenju odluka, neizvjesnost ishoda dijagnostičkih i terapijskih intervencija, kontakt s oboljelima i njihovim obiteljima i emocionalno iscrpljivanje (engl. burn-out) u zdravstvenih djelatnika pridonose povećanom morbiditetu od psihičkih smetnji i psihosomatskih bolesti (Sauter, 1999.).

\section{Vrste i uzroci stresa}

Postoje dvije osnovne vrste stresa koje su razlikuju po trajanju (Sambol, 2009.), a to su akutni i kronični stres. Akutni stres je trenutna reakcija na jednokratni događaj do čije pojave dolazi brzo, ali isto tako brzo i nestaje (npr. prometna nesreća, sukob s bliskom osobom, polaganje ispita). Utjecaj akutnog stresa može trajati od nekoliko minuta i sati pa do nekoliko dana ili tjedana. Kronični stres uzrokovan je konstantnim nizom stresnih događaja ili nekom dugotrajnom situacijom (npr. teško poslovno okruženje, briga za kronično oboljelu osobu).

Izvori stresa (stresori) dijele se u tri skupine:

- Fiziološke stresore - izloženost jakoj buci, velikoj vrućini ili hladnoći te jakoj boli.

- Psihološke stresore - uvjetovane međuljudskim nesporazumima i sukobima sa članovima obitelji, susjedima, kolegama i rukovoditeljima na poslu.
- Socijalne stresore - kada se radi o sukobima, krizama i katastrofama koje potresaju gotovo sve ljude u nekom društvu (ekonomske krize, ratovi, nagle promjene društvenih odnosa); (Havelka, 1998.).

Najčešće stresne situacije koje rezultiraju doživljajem psihičkog stresa (prema Hudek-Knežević, Kardum, 2006.) uključuju velike životne promjene (vjenčanje, završetak škole, smrt voljene osobe); kronične stresne događaje (nezaposlenost, svađe u obitelji); traumatske događaje (prirodne i tehnološke katastrofe, ratne situacije i osobne traume); svakodnevne stresne situacije (žurba, gužva, neljubaznost ljudi).

Osim dimenzija trajanja i intenziteta stresa različitih stresnih događaja, važne dimenzije stresnih situacija koje djeluju kako na načine suočavanja sa stresom, tako i na zdravstvene ishode, su (ne)mogućnost kontrole stresnog događaja, iznenadnost i (ne)predvidljivost stresnog događaja.

\section{Profesionalni stres}

Profesionalni stres definira se kao stanje praćeno fizičkim, psihičkim ili socijalnim smetnjama ili disfunkcijama koje su posljedica nesklada između zahtjeva radnog mjesta i okoline spram mogućnosti, želja i očekivanja pojedinca da tim zahtjevima udovolji. Takav stres nije bolest, ali produljena izloženost pritiscima može smanjiti učinkovitost na radu ili može voditi k pogoršanju zdravlja (Pavičević, Bobić, 2002.).

Izvori profesionalnog stresa mogu biti unutrašnji i vanjski (Ajduković, 1996.). Unutrašnji izvori stresa prvenstveno ovise o pojedincu, a očituju se kao nerealna očekivanja od posla i od sebe, potreba za stalnom i potpunom kontrolom situacije, pretjerana povezanost s poslom i osjećaj pojedinca da snosi svu odgovornost, nedelegiranje poslova drugima te pretjerana upornost i rigidnost u postizanju cilja „po bilo koju cijenu“. Vanjski izvori profesionalnog stresa povezani su s radnim uvjetima, organizacijom rada i odnosima s drugim ljudima (Škrinjar, 1994.).

Profesija pružatelja zdravstvenih usluga smatra se visoko stresnim zanimanjem. Stresori koji se mogu identificirati u profesiji medicinskih sestara/tehničara su: nemogućnost pružanja dovoljne 
zdravstvene pomoći zbog objektivnih okolnosti (nedostatak sredstava); neizvjesnost oko ishoda pružene pomoći; osjećaj prevelike odgovornosti za bolesnika; rad s teškim bolesnicima kod kojih je uspjeh njege neizvjestan; rad sa žrtvama nasilja; problemi u odnosu sa članovima obitelji bolesnika; ugroženost vlastitog zdravlja i sigurnosti; autoritativni odnos liječnika prema medicinskoj sestri/tehničaru (Ajduković, 1996., Cuculić 2006., Gray-Toft, 1981.).

Stresori u odnosu na samu organizaciju rada uključuju: nejasnost uloga; visoke zahtjeve, kratke rokove, prekovremeni rad; lošu radnu atmosferu - nedostatak podrške rukovoditelja, mala potpora okoline, međusobna netrpeljivost zaposlenih; niska primanja; opterećenost administrativnim dijelom posla; osjećaj pretjerane eksploatiranosti; pomanjkanje kontrole nad vremenom, učinkom i načinom rada; smanjen broj radnika (Ajduković, 1996., Cooper, 1988., Cuculić, 2006.).

Stres na radnom mjestu odražava se na radni učinak, kvalitetu obavljenog posla, tijek procesa, broj pogrešaka te povećanje broja ozljeda, a posljedice uključuju povećanu fluktuaciju zaposlenika, odsutnost s posla te povećanu stopu bolovanja. Važno je istaknuti kako ne postoji oštra granica između normalnog fiziološkog i patološkog stresa te da je stupanj tolerancije na stres individualan.

U literaturi su opisane i tzv. nepatološke reakcije na stres (Raphael, Meldrum, 1995., Alexander 2000., Murray et al., 2018.) koje uključuju: usvajanje novih vještina rješavanja problema i veća bliskost sa značajnim osobama; povećanje osobne kontrole i samodiscipline; pronalaženje pozitivnih aspekata i značenja stresne situacije, preuređivanje životnih ciljeva i prioriteta; povećanje osobnih i socijalnih (obiteljska podrška) resursa; povećanje sposobnosti cijenjenja života i boljeg suosjećanja s drugima; promjene u samopercepciji, međuljudskim odnosima i životnoj filozofiji; pozitivne promjene u stavovima, temeljnim uvjerenjima ili vrijednostima.

\section{Sindrom izgaranja}

Jedna od najnepovoljnijih posljedica dugotrajne izloženosti profesionalnom stresu, koja nastaje kao reakcija na kronične izvore stresa u radu, upravo je izgaranje na poslu (Ajduković, 1996.). Popularan izraz za patološki profesionalni stres je "burn out" sindrom (Martin et al., 1997.), tj. sindrom izgaranja na poslu koji označava progresivni gubitak idealizma, energije i smislenosti vlastitog rada kao rezultat frustracija i stresa na poslu. Termin "burnout" ili izgaranje označava stanje emocionalnog i psihičkog iscrpljenja na poslu. On je čest kod tzv. "pomagačkih profesija" (liječnici, medicinske sestre, socijalni radnici, psiholozi). Posljedice mogu biti vrlo ozbiljne za osoblje, pacijente i institucije u kojima se nalaze. Utjecaj na mentalno zdravlje je kompleksan: s jedne strane posao je izvor osobnog zadovoljstva i postignuća, međuljudske interakcije i financijske sigurnosti, što se smatra pozitivnim utjecajima na mentalno zdravlje. S druge strane, loša organizacija na poslu, narušeni međuljudski odnosi, vremenski rokovi, donošenje odluka, smjenski rad i slično mogu negativno utjecati na mentalno zdravlje i osjećaj dobrobiti pojedinca. Izgaranje na poslu je postupan proces pri kojem produktivan i odgovoran radnik gubi sav interes za svoj posao odnosno profesiju. Psihosocijalna klima i uzajamni odnosi obilježeni rivalitetom, nepovjerenjem, sumnjičavošću, sputavanjem samostalnosti i kreativnosti, nesigurnošću, natjecateljskim odnosom itd., pridonijet će izgaranju na poslu jer se silna energija mora ulagati u "preživljavanje" unutar takvog radnog okruženja (Cuculić, 2006.).

\section{HIPOTEZA I CILJ ISTRAŽIVANJA}

\section{Hipoteza}

Uvjeti radnog okoliša važan su čimbenik za nastanak profesionalnog stresa i sindroma izgaranja kod djelatnika intenzivne psihijatrijske skrbi i hitne medicine.

\section{Opći ciljevi rada}

Opći ciljevi rada su:

1. Istražiti prisutnost $\mathrm{i}$ intenzitet profesionalnog stresa i sindroma izgaranja kod djelatnika intenzivne psihijatrijske skrbi i hitne medicine.

2. Istražiti čimbenike psihofizioloških napora povezanih s većim intenzitetom stresa $u$ ispitanika. 
3. Istražiti čimbenike povezane sa sindromom izgaranja u ispitanika.

\section{METODOLOGIJA ISTRAŽIVANJA}

\section{Ispitanici}

$U$ istraživanje bili su uključeni djelatnici intenzivne psihijatrijske skrbi Klinike za psihijatriju Vrapče $(\mathrm{N}=63)$ i djelatnici Nastavnog zavoda za hitnu medicinu Grada Zagreba ( $\mathrm{N}=63)$. Pismeno su zatražene i dobivene dozvole od Etičkih povjerenstava obje navedene ustanove. $U$ istraživanju su korištena tri standardizirana upitnika za samoprocjenu. Uz upitnike su prikupljeni i osnovni demografski podaci ispitanika. Ispitanici su bili informirani i detaljno upoznati s razlogom ovog istraživanja. Odluka o sudjelovanju u istraživanju bila je dobrovoljna, a ispunjavanje upitnika bilo je anonimno uz informirani pristanak ispitanika. Istraživanje je provedeno tijekom lipnja i srpnja 2018. godine.

\section{Metode}

Za potrebe istraživanja korišten je Upitnik o stresorima na radnom mjestu bolničkih zdravstvenih djelatnika (Milošević, 2010.); (Prilog 1); (u nastavku teksta: Upitnik), kojim su se ispitivale sociodemografske značajke ispitanika i stresori na radnom mjestu. Ispitanicima je ponuđeno 37 stresora na radu, a svoj doživljaj određenog stresora ocjenjivali su na Likertovoj ljestvici ocjenama od 1 (Nije uopće stresno) do 5 (Izrazito stresno).

Skala profesionalnog stresa preuzeta je sa službenih mrežnih stranica Hrvatskog zavoda za zaštitu zdravlja i sigurnost na radu (Prilog 2). Obuhvaćeno je 11 kategorija stresa na radu, a svaka kategorija sadržavala je pet pitanja te je ukupni zbroj po kategoriji mogao imati raspon od 5 do 25. Rezultat 14 i više upućuje na problematične kategorije, dok ukupni zbroj svih pitanja koji je veći od 135 upućuje na visoku razinu stresa.

Za procjenu sindroma izgaranja korišten je upitnik (Prilog 3) koji je konstruiran unutar aktivnosti Društva za psihološku pomoć (Ajduković, 1996.) i sastoji se od 18 tvrdnji koje predstavljaju različite simptome izgaranja na poslu. Sudionici na skali od 1 do 3 procjenjuju prisutnost određenog ponašanja, pri čemu 1 znači da su simptomi stresa rijetki i imaju manju izraženost, a 3 da je navedeno ponašanje uvijek prisutno uz veću izraženost simptoma. Ukupan rezultat izražava se kao zbroj svih zaokruženih odgovora tako da se teoretski raspon rezultata kreće od 18 do 54 . Ovaj upitnik već je upotrebljavan u svrhu mjerenja izgaranja na poslu kod pomažućih profesija. Upitnik ima zadovoljavajuću pouzdanost koja iznosi 0,845 (Cronbach alpha koeficijent).

\section{Statističke metode}

Za analizu normalnosti raspodjele numeričkih podataka korišten je Smirnov-Kolmogorovljev test. Kvantitativni podaci prikazani su kroz raspone, aritmetičke sredine i standardne devijacije, odnosno medijane i interkvartilne raspone u slučajevima neparametrijske raspodjele. Kategorijski podaci prikazani su kroz apsolutne frekvencije i pripadajuće udjele. Razlike u kvantitativnim vrijednostima između pojedinih skupina (ispitivane u odnosu na kontrolnu) procijenjene su nezavisnim t-testom, Mann-Whitney $U$ testom. Razlike u kategorijskim varijablama između ispitivanih skupina analizirale su se $\chi 2$ testom. Izračunati su odgovarajući koeficijenti korelacije (Spearman). Sve P vrijednosti manje od 0,05 smatraju se značajnima. Pri obradi je korišten statistički program SPSS, verzija 20.

\section{REZULTATI}

\section{Sociodemografske značajke ispitanika}

Istraživanje je provedeno na ukupno 126 ispitanika (63 djelatnika intenzivne psihijatrijske skrbi Klinike za psihijatriju Vrapče i 63 djelatnika Nastavnog zavoda za hitnu medicinu Grada Zagreba) korištenjem Upitnika o sociodemografskim karakteristikama ispitanika (Prilog 1.). Struktura ispitanika po spolu (Tablica 1.) pokazuje razdiobu na 66 muških ispitanika (52 \%) i 60 ženskih ispitanika (48\%), a u odnosu na ustanove u kojima su zaposleni, veći broj ženskih ispitanika je u Klinici za psihijatriju Vrapče $(\mathrm{N}=38)$, a veći broj muških ispitanika u Nastavnom zavodu za hitnu medicinu Grada Zagreba $(\mathrm{N}=41)$. 
Tablica 1. Prikaz spolne, dobne, obrazovne i bračne strukture obilježja ispitanika

Table 1. Participants shown by sex, age, education, and marital status

\begin{tabular}{|c|c|c|c|c|c|c|c|}
\hline & & \multicolumn{4}{|c|}{ Ustanova } & \multicolumn{2}{|c|}{ Ukupno } \\
\hline & & \multicolumn{2}{|c|}{ Hitna } & \multicolumn{2}{|c|}{ Vrapče } & \multirow{2}{*}{$N$} & \multirow{2}{*}{$\%$} \\
\hline & & $\mathbf{N}$ & $\%$ & $\mathbf{N}$ & $\%$ & & \\
\hline \multicolumn{2}{|c|}{ Ukupni broj } & 63 & 100 & 63 & 100 & 126 & 100 \\
\hline \multirow{4}{*}{ Starost } & $20-29$ & 20 & 32 & 16 & 25 & 36 & 29 \\
\hline & $30-39$ & 14 & 22 & 15 & 24 & 29 & 23 \\
\hline & $40-49$ & 20 & 32 & 16 & 25 & 36 & 29 \\
\hline & $50-61$ & 9 & 14 & 16 & 25 & 25 & 20 \\
\hline \multirow{2}{*}{ Spol } & muško & 41 & 65 & 25 & 40 & 66 & 52 \\
\hline & žensko & 22 & 35 & 38 & 60 & 60 & 48 \\
\hline \multirow{3}{*}{$\begin{array}{c}\text { Završena } \\
\text { stručna } \\
\text { sprema }\end{array}$} & SSS & 33 & 52 & 47 & 75 & 80 & 63 \\
\hline & VŠS & 8 & 13 & 12 & 19 & 20 & 16 \\
\hline & VSS & 22 & 35 & 4 & 6 & 26 & 21 \\
\hline \multirow{2}{*}{ Bračno stanje } & partner & 38 & 60 & 39 & 62 & 77 & 61 \\
\hline & samac & 25 & 40 & 24 & 38 & 49 & 39 \\
\hline \multirow{5}{*}{ Broj djece } & 0 & 30 & 48 & 23 & 37 & 53 & 42 \\
\hline & 1 & 3 & 5 & 11 & 17 & 14 & 11 \\
\hline & 2 & 22 & 35 & 22 & 35 & 44 & 35 \\
\hline & 3 & 8 & 13 & 5 & 8 & 13 & 10 \\
\hline & 4 & 0 & 0 & 2 & 3 & 2 & 2 \\
\hline
\end{tabular}

Jednak broj ispitanika $(\mathrm{N}=36)$ bio je u starosnim razredima od 20 do 29 godina te od 40 do 49 godina, dok je u starosnom razredu od 30 do 39 godina bilo 29 ispitanika (23\%), a preostalih 25 ispitanika bilo je u starosnom razredu od 50 do 61 godine (20\%) gledajući starosne kategorije (Tablica 1.). Prema stupnju obrazovanja, prvu skupinu čine ispitanici sa završenom srednjom stručnom spremom $(\mathrm{N}=80)$, u drugoj skupini su ispitanici s višom stručnom spremom $(\mathrm{N}=20)$, a u trećoj skupini su ispitanici s visokom stručnom spremom ( $\mathrm{N}=26)$; (Tablica 1.). Ukupno 77 ispitanika (61\%) ima partnera, a 49 ispitanika (39 \%) su samci (Tablica 1.) Od ukupnog broja ispitanika njih 53 (42\%) nema djece, 14 (11\%) ima jedno dijete, 44 ispitanika (35\%) ima dvoje djece, a preostalih 15 (12\%) troje i više djece (Tablica 1.).

Postoje razlike u kategorijama radnog mjesta u odnosu na ustanove u kojima je istraživanje provedeno. Tako su u Klinici za psihijatriju Vrapče svi ispitanici $(\mathrm{N}=63)$ zaposleni u jedinicama intenzivne skrbi, dok je u Nastavnom zavodu za hitnu medicinu Grada Zagreba 50 ispitanika zaposleno u Timu 1 (kojeg čine liječnik, medicinski tehničar/sestra i vozač), četiri ispitanika rade u Timu 2 (dva medicinska tehničara/sestre), a devet ispitanika radi na poslovima sanitetskog prijevoza (medicinski tehničar i vozač); (Tablica 2.). 
Tablica 2. Prikaz radnog mjesta, radnog staža i prosječnog broja sati rada tjedno

Table 2. Type of workplace, length of service, and average weekly hours

\begin{tabular}{|c|c|c|c|c|c|c|c|}
\hline & & \multicolumn{4}{|c|}{ Bolnica } & \multicolumn{2}{|c|}{ Ukupno } \\
\hline & & \multicolumn{2}{|c|}{ Hitna } & \multicolumn{2}{|c|}{ Vrapče } & \multirow{2}{*}{$\mathbf{N}$} & \multirow{2}{*}{$\%$} \\
\hline & & $\mathbf{N}$ & $\%$ & $\mathbf{N}$ & $\%$ & & \\
\hline \multicolumn{2}{|c|}{ Ukupni broj } & 63 & 100 & 63 & 100 & 126 & 100 \\
\hline \multirow{4}{*}{ Radno mjesto } & Tim 1 & 50 & 79 & 0 & 0 & 50 & 40 \\
\hline & Tim 2 & 4 & 6 & 0 & 0 & 4 & 3 \\
\hline & prijevoz & 9 & 14 & 0 & 0 & 9 & 7 \\
\hline & intenzivna & 0 & & 63 & 100 & 63 & 50 \\
\hline \multirow{7}{*}{$\begin{array}{l}\text { Ukupni radni } \\
\text { staž }\end{array}$} & $0-3$ & 16 & 25 & 11 & 17 & 27 & 21 \\
\hline & $3-5$ & 2 & 3 & 1 & 2 & 3 & 2 \\
\hline & $5-10$ & 2 & 3 & 6 & 10 & 8 & 6 \\
\hline & $10-15$ & 6 & 10 & 9 & 14 & 15 & 12 \\
\hline & $15-20$ & 12 & 19 & 5 & 8 & 17 & 13 \\
\hline & $20-30$ & 20 & 32 & 16 & 25 & 36 & 29 \\
\hline & 30 ili više & 5 & 8 & 15 & 24 & 20 & 16 \\
\hline \multirow{2}{*}{$\begin{array}{c}\text { Sezonski } \\
\text { zaposlenik }\end{array}$} & da & 2 & 3 & 0 & 0 & 2 & 2 \\
\hline & ne & 61 & 97 & 63 & 100 & 124 & 98 \\
\hline \multirow{4}{*}{$\begin{array}{l}\text { Prosječni sati } \\
\text { rada tjedno }\end{array}$} & 40 sati & 14 & 22 & 22 & 35 & 36 & 29 \\
\hline & $40-45$ & 10 & 16 & 12 & 19 & 22 & 17 \\
\hline & $45-50$ & 27 & 43 & 25 & 40 & 52 & 41 \\
\hline & 50 i više & 12 & 19 & 4 & 6 & 16 & 13 \\
\hline
\end{tabular}

Što se tiče radnog staža, 27 ispitanika (21 \%) ima do tri godine radnog staža, a najveći broj ispitanika ( $\mathrm{N}=36 ; 29 \%)$ ima od 20 do 30 godina rad- nog staža (Tablica 2.). Ukupno 36 ispitanika (29 \%) radi prosječno 40 sati tjedno, najveći broj ispitanika $(\mathrm{N}=52)$ radi između 45 i 50 sati tjedno (Tablica 2.). 
Tablica 3. Korištenje bolovanja u ispitanika

Table 3. Absenteeism

\begin{tabular}{|c|c|c|c|c|c|c|c|}
\hline & & \multicolumn{4}{|c|}{ Bolnica } & \multicolumn{2}{|c|}{ Ukupno } \\
\hline & & \multicolumn{2}{|c|}{ Hitna } & \multicolumn{2}{|c|}{ Vrapče } & \multirow{2}{*}{$\mathbf{N}$} & \multirow{2}{*}{$\%$} \\
\hline & & $\mathbf{N}$ & $\%$ & $\mathbf{N}$ & $\%$ & & \\
\hline \multicolumn{2}{|c|}{ Ukupni broj } & 63 & 100 & 63 & 100 & 126 & 100 \\
\hline \multirow{2}{*}{$\begin{array}{l}\text { Bolovanje u zadnjih } \\
\text { godinu dana }\end{array}$} & da & 23 & 37 & 27 & 43 & 50 & 40 \\
\hline & ne & 39 & 62 & 36 & 57 & 75 & 60 \\
\hline \multirow{5}{*}{ Broj dana bolovanja } & $0-10$ & 8 & 33 & 10 & 36 & 18 & 35 \\
\hline & $10-30$ & 3 & 13 & 7 & 25 & 10 & 19 \\
\hline & $30-60$ & 6 & 25 & 4 & 14 & 10 & 19 \\
\hline & $60-90$ & 4 & 17 & 3 & 11 & 7 & 13 \\
\hline & 90 i više & 3 & 13 & 4 & 14 & 7 & 13 \\
\hline \multirow{10}{*}{ Dijagnoza } & respiratorni & 8 & 32 & 8 & 29 & 16 & 30 \\
\hline & lokomotorni & 11 & 44 & 5 & 18 & 16 & 30 \\
\hline & ozljede na radu & 2 & 8 & 0 & 0 & 2 & 4 \\
\hline & gastro & 3 & 12 & 2 & 7 & 5 & 9 \\
\hline & endokrinološka & 1 & 4 & 1 & 4 & 2 & 4 \\
\hline & bolest djeteta & 0 & 0 & 6 & 21 & 6 & 11 \\
\hline & okulistika & 0 & 0 & 1 & 4 & 1 & 2 \\
\hline & autoimuna & 0 & 0 & 1 & 4 & 1 & 2 \\
\hline & kardiovaskularne & 0 & 0 & 2 & 7 & 2 & 4 \\
\hline & ginekološki & 0 & 0 & 2 & 7 & 2 & 4 \\
\hline
\end{tabular}

Ispitanici su upitani i o korištenju bolovanja u zadnjih godinu dana koja je prethodila početku ispitivanja (Tablica 3.). Ukupno 50 ispitanika (40 \%) bilo je na bolovanju u navedenom razdoblju (od toga 23 zaposlenika Nastavnog zavoda za hitnu medicinu Grada Zagreba te 27 zaposlenika Klinike za psihijatriju Vrapče), dok ukupno 75 ispitanika (60\%) nije koristilo bolovanje posljednjih godinu dana. Najviše ispitanika $(\mathrm{N}=18$; $35 \%$ ) bilo je na bolovanju do deset dana, a uku- pno sedam ispitanika (13\%) bilo je na bolovanju koje je trajalo dulje od tri mjeseca. Najčešći razlozi odlaska na bolovanje su bolesti respiratornog trakta $(\mathrm{N}=16)$ i bolesti lokomotornog sustava $(\mathrm{N}=16)$. Dva ispitanika (4 \% od ukupnog broja; svi zaposleni u Nastavnom zavodu za hitnu medicinu Grada Zagreba) bili su na bolovanju zbog ozljede na radu, a šest ispitanika (11\% od ukupnog broja; svi zaposlenici Klinike za psihijatriju Vrapče) zbog bolesti djeteta. 


\section{Profesionalni stres}

Upitnik Stres na radnom mjestu bolničkih zdravstvenih djelatnika (Prilog 2.) ispituje izvore stresa (stresore). Rezultati (slika 1.) prikazuju učestalost pojedinih odgovora na svih 37 ponuđenih pitanja podijeljenih u šest kategorija: „Organizacija radnog mjesta i financijska pitanja“, "Javna kritika i sudske tužbe", "Opasnosti i štetnosti na poslu", "Sukobi i komunikacija na poslu", "Smjenski rad", „Profesionalni i intelektualni zahtjevi“. Odgovori su kodirani Likertovom ljestvicom raspona: 1 (Nije uopće stresno), 2 (Rijetko je stresno), 3 (Ponekad je stresno), 4 (Stresno) i 5 (Izrazito stresno), pri čemu su odgovori 4 (Stresno) i 5 (Izrazito stresno) objedinjeni kao odgovori koji upućuju na stalnu prisutnost stresa. Stresor pod nazivom "Preopterećenost poslom" smatra dominantnim izvorom $70 \%$ svih ispitanika $(\mathrm{N}=88)$. Ovaj stresor statistički je značajno povezan sa stresorima: "Nedostatan broj djelatnika" (68\%), "Neadekvatna osobna primanja" (67\%) i "Svakodnevne nepredviđene situacije" (63\%). Njih 68 \% smatra kako je "Nedostatan broj djelatnika" sljedeći po važnosti stresnih čimbenika. „Neadekvatna osobna primanja" $67 \%$ ispitanika smatra trećim čimbenikom stresa povezanim s intenzitetom stresa. Najmanji doprinos osjećaju stresa ima "Strah zbog izloženosti citostaticima" (12\% ispitanika).

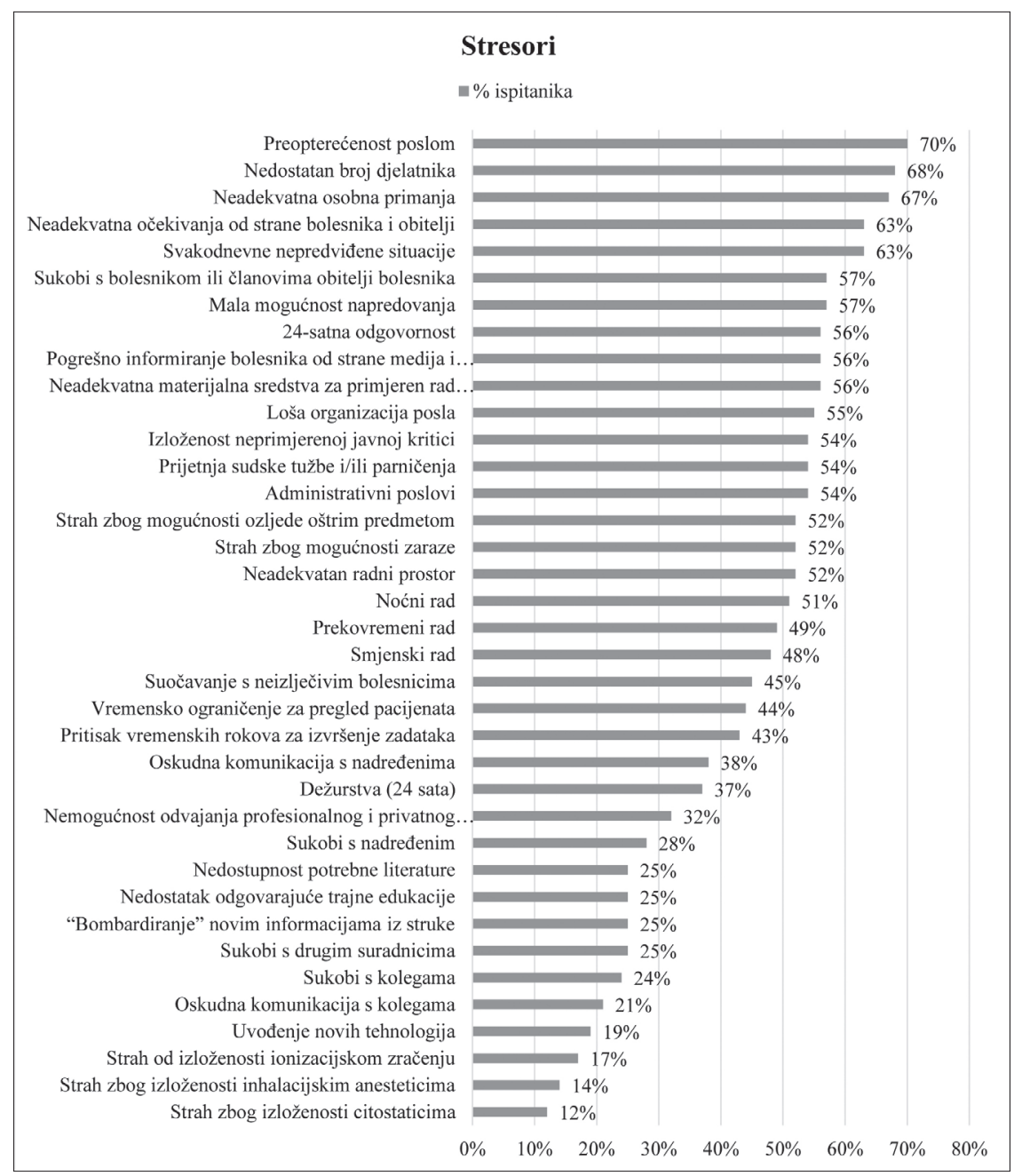

Slika 1. Prikaz učestalosti stresora ocijenjenih s ocjenom 4 (stresno) i 5 (izrazito stresno) u ukupnom broju ispitanika $(\mathrm{N}=126)$

Figure 1. Stressor frequency marked 4 (stressful) and 5 (exceptionally stressful) among the total number of participants $(\mathrm{N}=126)$ 
Statistički značajne razlike među pojedinim izvorima stresa, ocijenjenih s ocjenom $4 \mathrm{i}$ 5, među djelatnicima Hitne i Vrapče, prikazane su na slici 2. i 2a te između djelatnika Hitne i Vrapče na slici 3. Kod djelatnika Hitne dominantan stresor je "Neadekvatna očekivanja od strane bolesnika i obitelji“ što navodi $70 \%$ ispitanika te "Mala mogućnost napredovanja" što navodi $65 \%$ ispitanika (slika 2.). Kao slab izvor stresora uočava se "Strah zbog izloženosti citostaticima" jer ga navodi samo $13 \%$ ispitanika (slika 2.). Kod djelatnika bolnice Vrapče dominantni izvori stresora su "Nedostatan broj djelatnika" koji je navelo $84 \%$ ispitanika i "Neadekvatna osobna primanja" koje navodi $71 \%$ ispitanika (slika 2a.) Slab izvor stresora je „Strah zbog izloženosti citostaticima" jer ga je navelo samo $11 \%$ ispitanika (slika 2a.). Razlika među značajnosti stresora između djelatnika Hitne i Vrapče prikazana je na slici 3.

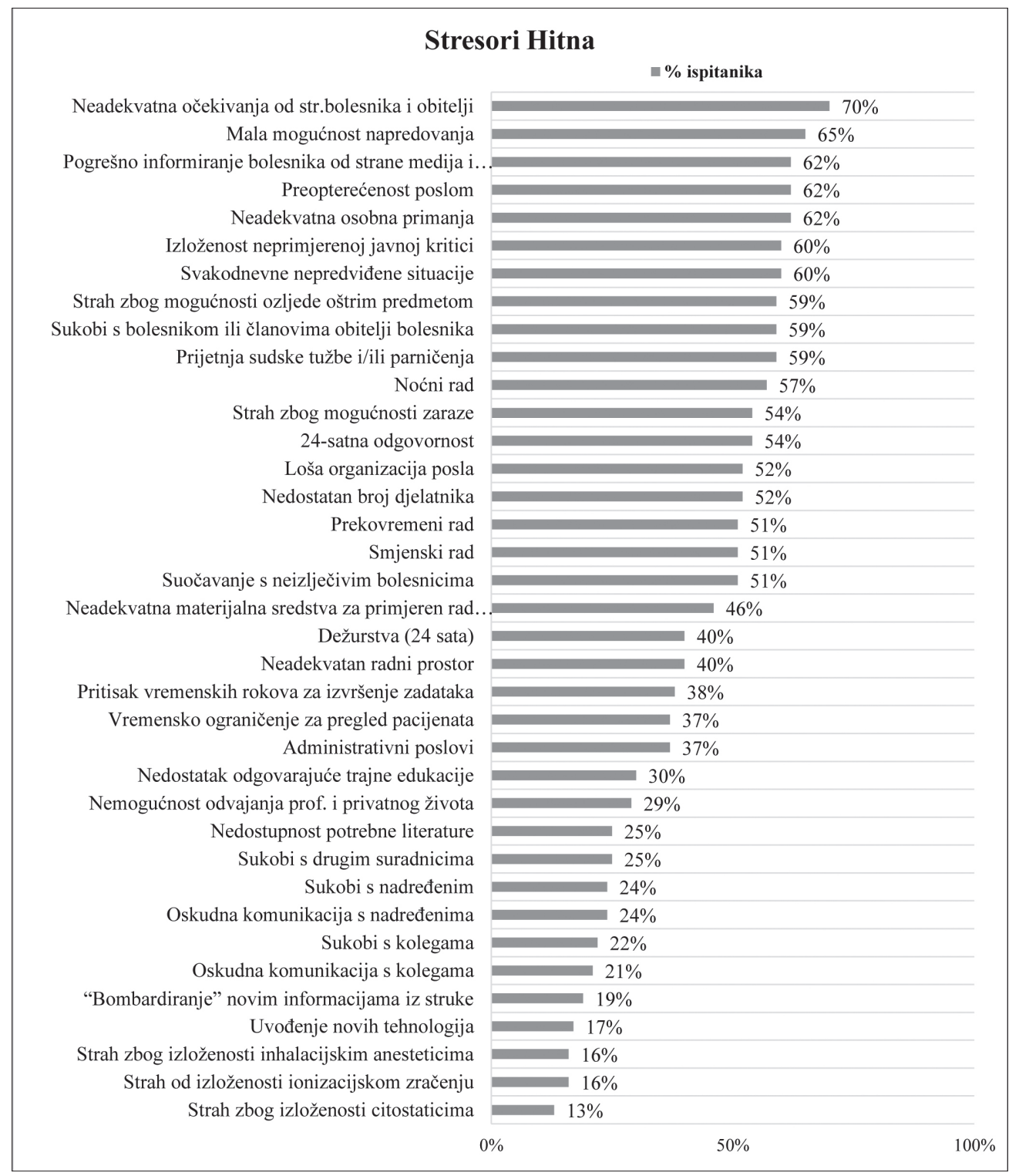

Slika 2. Distribucija stresora ocijenjenih s ocjenom 4 (stresno) i 5 (izrazito stresno) u djelatnika Hitne $(\mathrm{N}=63)$

Figure 2. Distribution of stressors marked 4 (stressful) and 5 (exceptionally stressful) experienced by Emergency Medicine employees $(\mathrm{N}=63)$ 


\section{Stresori Vrapče}

\begin{tabular}{|c|c|}
\hline \multirow{3}{*}{$\begin{array}{l}\text { Neadekvatna očekivanja od str. bolesnika i obitelji } \\
\text { Mala mogućnost napredovanja }\end{array}$} & \% ispitanika \\
\hline & $57 \%$ \\
\hline & $49 \%$ \\
\hline \multicolumn{2}{|c|}{ Pogrešno informiranje bolesnika od strane medija i... $51 \%$} \\
\hline Preopterećenost poslom & $78 \%$ \\
\hline Neadekvatna osobna primanja & $71 \%$ \\
\hline Izloženost neprimjerenoj javnoj kritici & $48 \%$ \\
\hline Svakodnevne nepredviđene situacije & $67 \%$ \\
\hline \multirow{3}{*}{$\begin{array}{l}\text { Strah zbog mogućnosti ozljede oštrim predmetom } \\
\text { ukobi s bolesnikom ili članovima obitelji bolesnika } \\
\text { Prijetnja sudske tužbe i/ili parničenja }\end{array}$} & $46 \%$ \\
\hline & $56 \%$ \\
\hline & $49 \%$ \\
\hline Noćni rad & $44 \%$ \\
\hline Strah zbog mogućnosti zaraze & $49 \%$ \\
\hline 24-satna odgovornost & $59 \%$ \\
\hline Loša organizacija posla & 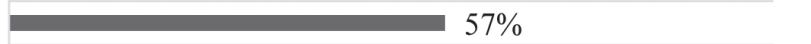 \\
\hline Nedostatan broj djelatnika & $84 \%$ \\
\hline Prekovremeni rad & $48 \%$ \\
\hline Smjenski rad & $46 \%$ \\
\hline Suočavanje s neizlječivim bolesnicima & $40 \%$ \\
\hline Neadekvatna materijalna sredstva za primjeren rad. & $65 \%$ \\
\hline Dežurstva (24 sata) & $35 \%$ \\
\hline Neadekvatan radni prostor & $63 \%$ \\
\hline \multirow{2}{*}{$\begin{array}{l}\text { Pritisak vremenskih rokova za izvršenje zadataka } \\
\text { Vremensko ograničenje za pregled pacijenata }\end{array}$} & $48 \%$ \\
\hline & $51 \%$ \\
\hline Administrativni poslovi & $71 \%$ \\
\hline Nedostatak odgovarajuće trajne edukacije & $19 \%$ \\
\hline Nemogućnost odvajanja prof. i privatnog života & $35 \%$ \\
\hline Nedostupnost potrebne literature & $25 \%$ \\
\hline Sukobi s drugim suradnicima & $25 \%$ \\
\hline Sukobi s nadređenim & $32 \%$ \\
\hline Oskudna komunikacija s nadređenima & $52 \%$ \\
\hline Sukobi s kolegama & $25 \%$ \\
\hline Oskudna komunikacija s kolegama & $22 \%$ \\
\hline "Bombardiranje" novim informacijama iz struke & $30 \%$ \\
\hline Uvođenje novih tehnologija & $21 \%$ \\
\hline Strah zbog izloženosti inhalacijskim anesteticima & $13 \%$ \\
\hline Strah od izloženosti ionizacijskom zračenju & $17 \%$ \\
\hline Strah zbog izloženosti citostaticima & $11 \%$ \\
\hline & $100 \%$ \\
\hline
\end{tabular}

Slika 2a. Distribucija stresora ocijenjenih s ocjenom 4 (stresno) i 5 (izrazito stresno) u djelatnika Vrapče (N=63) Figure 2a. Distribution of stressors marked 4 (stressful) and 5 (exceptionally stressful) experienced by employees at Vrapče Psychiatric Hospital ( $N=63)$ 


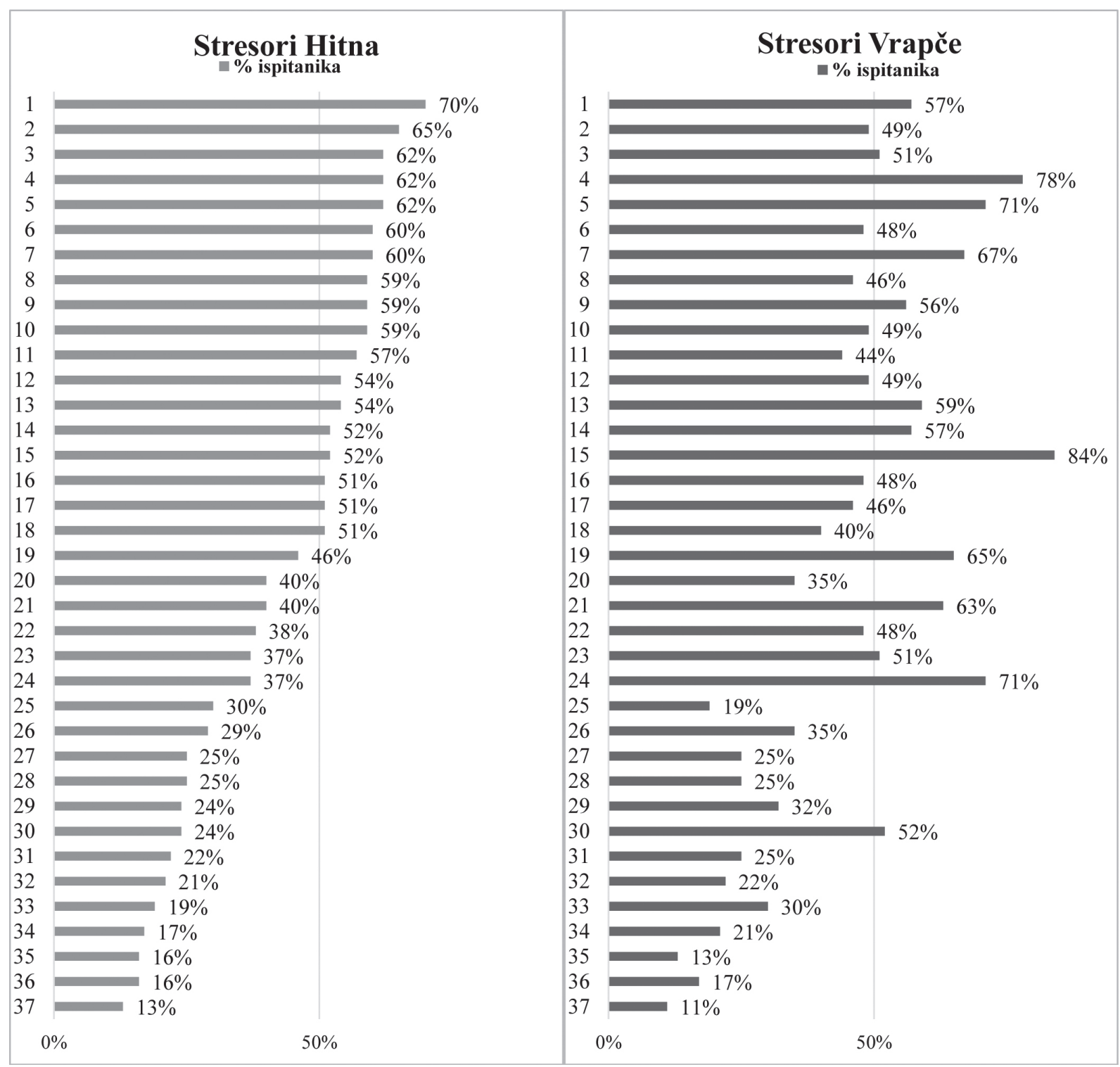

Legenda: Brojevi 1-37 odgovaraju nazivima stresora sa slika 2 i 2 a.

Slika 3. Usporedni prikaz razlika među stresorima ocijenjenih s ocjenom 4 (stresno) i 5 (izrazito stresno) između djelatnika Hitne $(\mathrm{N}=63)$ i djelatnika Vrapče $(\mathrm{N}=63)$

Figure 3. Comparative differences in stressors marked 4 (stressful) and 5 (exceptionally stressful) exhibited by Emergency Medicine employees $(\mathrm{N}=63)$ vs. those at Vrapče Psychiatric Hospital $(\mathrm{N}=63)$ 
U Tablici 4. prikazane su kvantitativne vrijednosti na ukupnom broju ispitanika $(\mathrm{N}=126)$ gdje je nađena statistički značajna razlika u kategorijama "Organizacija i financije" $(P=0,004)$ "Opasnosti i štetnosti na poslu" $(P=0,046)$ te "Smjenski rad" $(P=0,046)$.

U kategorijama koje nisu statistički značajne ipak postoje određene čestice gdje postoje statistički značajne razlike, i to u kategoriji "Javna kritika i sudske tužbe" te čestici „Pogrešno informiranje bolesnika od strane medija i drugih izvora" $(P=0,049)$.

\section{Procjena psihofizioloških napora}

Sindrom izgaranja ispitivan je Upitnikom za procjenu psihofizioloških napora na radnom mjestu (Prilog 3.). U Tablici 5. prikazane su kvantitativne vrijednosti na ukupnom broju ispitanika ( $\mathrm{N}=126)$ gdje su nađene statistički značajne razlike u kategorijama "Pritisak na poslu“ $(P=0,001)$, pri čemu su tu razinu psihofiziološkog napora češće prijavljivali djelatnici Vrapča te kategoriji „Stres uzrokovan premalim radnim opterećenjem" $(P=0,004)$, gdje je ta vrsta napora bila češće prisutna u djelatnika Hitne. U kategoriji „Pritisak na poslu“ postoji statistički značajna razlika u čestici "Istovremeno moram obavljati nekoliko poslova" ( $P=0,000)$; (Tablica 5.). U kategoriji „Stres uzrokovan premalim radnim opterećenjem" nađena je statistički značajna razlika u česticama "Previše sam kvalificiran za posao koji obavljam" $(P=0,008)$ te "Mala je šansa za napredovanje" $(P=0,005)$.

Tablica 4. Statistički značajna razlika u ispitivanih kvantitativnih vrijednosti, ocijenjenih sa 4 i 5, po tvrdnjama unutar kategorija $(\mathrm{N}=126)$

Table 4. Statistically significant difference in investigated quantitative values marked 4 and 5 according to the statements within categories $(\mathrm{N}=126)$

\begin{tabular}{|c|c|c|c|c|c|}
\hline & \multicolumn{2}{|c|}{ Hitna $N=63$} & \multicolumn{2}{|c|}{ Vrapče $N=63$} & \multirow[b]{2}{*}{$P<0,05$} \\
\hline & $\begin{array}{c}\text { Aritmetička } \\
\text { sredina }\end{array}$ & $\%$ & $\begin{array}{l}\text { Aritmetička } \\
\text { sredina }\end{array}$ & $\%$ & \\
\hline 1. Organizacija i financije & 60,7 & $50 \%$ & 71,7 & $66 \%$ & ,004 \\
\hline 2. Javna kritika i sudske tužbe & 63,6 & $56 \%$ & 61,5 & $51 \%$ &, 553 \\
\hline 3. Opasnosti i štetnosti na poslu & 60,7 & $35 \%$ & 47,6 & $29 \%$ & ,046 \\
\hline 4. Sukob i komunikacija na poslu & 40,2 & $23 \%$ & 44,8 & $26 \%$ & ,253 \\
\hline 5. Smjenski rad & 59,9 & $50 \%$ & 47,6 & $43 \%$ & ,046 \\
\hline 6. Profesionalni i intelektualni zahtjevi & 36,8 & $28 \%$ & 43,4 & $32 \%$ &, 154 \\
\hline
\end{tabular}


Tablica 5. Prikaz ispitivanih kvantitativnih vrijednosti na uzorku ispitanika - zdravstvenih radnika ( $N=126)$

Table 5. Investigated quantitative values on the sample of healthcare employees $(\mathrm{N}=126)$

\begin{tabular}{|c|c|c|c|c|c|}
\hline \multirow[b]{2}{*}{ Neslaganje i neodlučnost } & \multicolumn{2}{|c|}{$\begin{array}{c}\text { Hitna } \mathbf{N}=\mathbf{6 3} \\
\text { Aritmetička sredina \% }\end{array}$} & \multicolumn{2}{|c|}{$\begin{array}{l}\text { Vrapče } \mathbf{N}=\mathbf{6 3} \\
\text { Aritmetička sredina \% }\end{array}$} & \multirow{2}{*}{$\begin{array}{c}\begin{array}{c}\text { Statistička } \\
\text { značajnost } \mathbf{P} \\
(<0,05)\end{array} \\
0,670\end{array}$} \\
\hline & 11,5 & 15 & 11,7 & 14 & \\
\hline Pritisak na poslu: & 14,7 & 35 & 17,1 & 51 & 0,001 \\
\hline $\begin{array}{l}\text { "Istovremeno moram obavljati } \\
\text { nekoliko poslova" }\end{array}$ & 14,72 & 23 & 17,05 & 27 & 0,000 \\
\hline Proturječnost u opisu posla & 12,6 & 24 & 11,9 & 23 & 0,719 \\
\hline $\begin{array}{c}\text { Komunikacija \& osjećaj opuštenosti u } \\
\text { radu s nadređenim }\end{array}$ & 12,9 & 24 & 13,3 & 23 & 0,502 \\
\hline $\begin{array}{l}\text { Zdravstveni problemi povezani s } \\
\text { poslom }\end{array}$ & 14,1 & 42 & 14,1 & 36 & 0,108 \\
\hline $\begin{array}{c}\text { Stres uzrokovan prevelikim radnim } \\
\text { opterećenjem }\end{array}$ & 12,4 & 22 & 12,1 & 16 & 0,831 \\
\hline $\begin{array}{l}\text { Stres uzrokovan premalim radnim } \\
\text { opterećenjem }\end{array}$ & 13,8 & 33 & 11,1 & 16 & 0,004 \\
\hline Stres uzrokovan dosadom & 10,5 & 18 & 11,8 & 20 & 0,504 \\
\hline Nesigurnost posla & 14,1 & 37 & 14,3 & 38 & 0,953 \\
\hline Vremenski rokovi & 13,3 & 30 & 13,3 & 29 & 0,578 \\
\hline Stres uzrokovan preprekama na poslu & 12,1 & 28 & 11,6 & 22 & 0,392 \\
\hline
\end{tabular}

Kako je vidljivo u Tablici 5., u kategorijama koje nisu statistički značajne ipak postoje određene čestice gdje postoje statistički značajne razlike: kategorija "Zabrinutost za zdravlje u vezi s radom" - čestica "Obavljanje teških fizičkih poslova na neprimjereni način" $(P=0,019)$, u djelatnika Hitne u odnosu na djelatnike Vrapča; kategorija "Dosada na poslu“ - čestica „Posao mi je prelagan" $(P=0,023)$, u djelatnika Hitne u odnosu na djelatnike Vrapča; kategorija "Nesigurnost posla" - čestica "Zabrinut za egzistenciju zbog male plaće" $(P=0,043)$, u djelatnika Vrapča; kategorija „Vremenski rokovi/pritisci" - čestica "Stalno me podsjećaju na rokove u kojima moram završiti

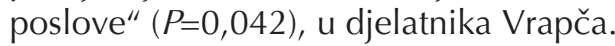

\section{Sindrom izgaranja}

Za potrebe procjene sindroma izgaranja korišten je Upitnik sindroma sagorijevanja. Njime se na skali od 1 do 3 procjenjuje prisutnost određenog ponašanja, pri čemu 1 znači da su simptomi stresa rijetki i imaju manju izraženost, a 3 da je navedeno ponašanje uvijek prisutno uz veću izraženost simptoma. Tvrdnju povezanu s izgaranjem na poslu, "Osjećam se nemoćnim da promijenim nešto na poslu", $46 \%$ ispitanika Hitne navodi glavnim uzrokom izgaranja, a kao drugi uzrok "Na poslu se osjećam umorno i iscrpljeno, čak i kad se dobro naspavam" navodi $25 \%$ ispitanika. Kao najrjeđi uzrok izgaranja (3\% ispitanika) na- 
vodi se „Primjećujem da se povlačim od kolega“ i "Sve što se traži od mene da uradim, doživljavam kao prisilu“. Kod djelatnika bolnice Vrapče tvrdnju „Osjećam se nemoćnim da promijenim nešto na poslu" kao glavni uzrok izgaranja na poslu navodi $32 \%$ ispitanika, dok je drugi po važnosti „Posao je veoma zamoran i rutinski" sa $22 \%$ zastupljenosti. Kao najrjeđi uzrok sindroma izgaranja (2\% ispitanika) je „Postajem sve neosjetljiviji/a i bešćutniji/a prema kolegama“ i „Provodim više vremena izbjegavajući posao nego radeći" navode ispitanici u bolnici Vrapče (slika 4.).

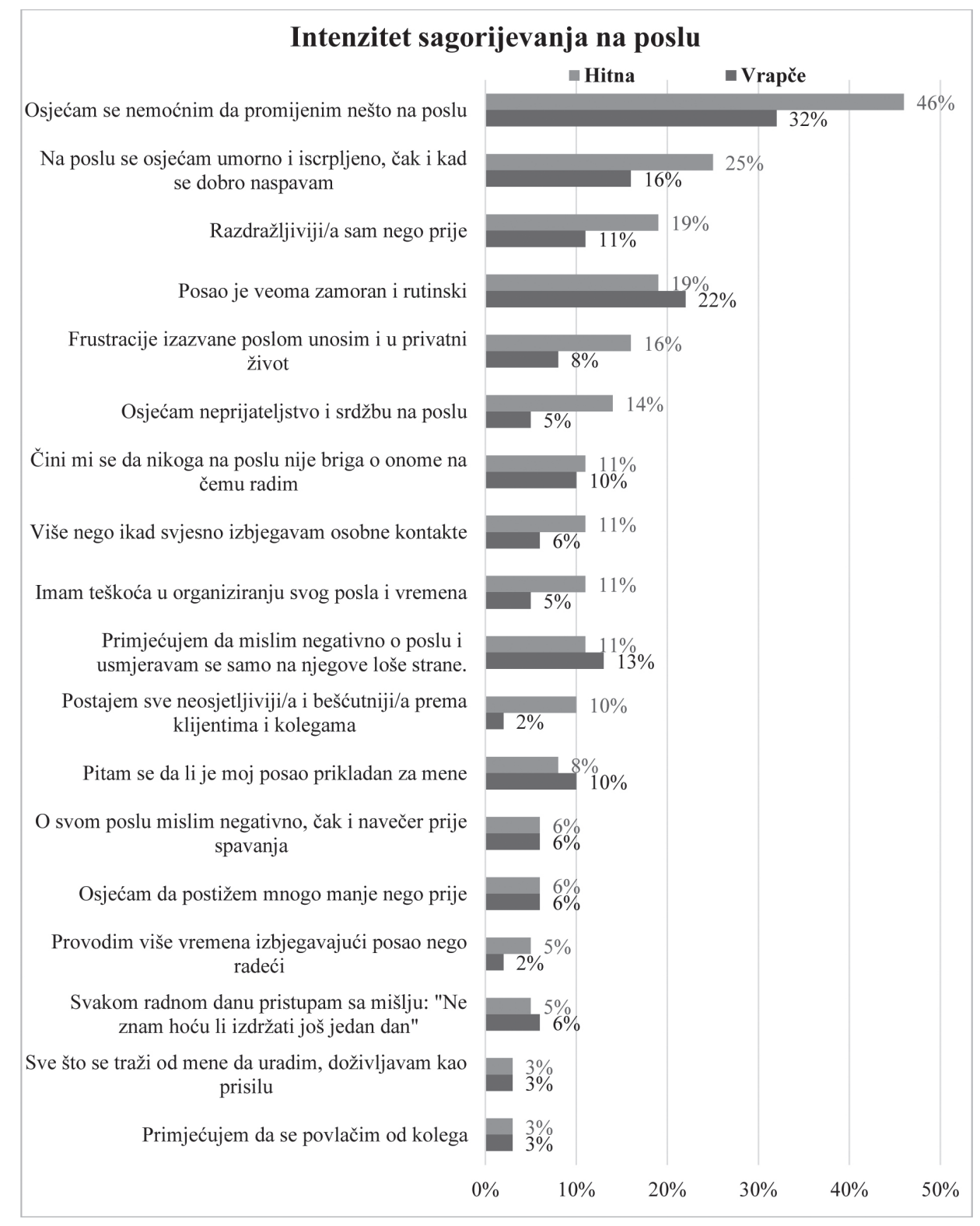

Slika 4. Distribucija rezultata na Upitniku intenziteta sagorijevanja na poslu

Figure 4. Results distribution in the Burnout Intensity Questionnaire 


\section{RASPRAVA}

Rad u zdravstvenom sektoru iznimno je zahtjevan i kompleksan, uzimajući u obzir multidimenzionalnost uloge zaposlenika gledane kroz prizmu radne okoline, razine odgovornosti, organizacije rada i načina komuniciranja u organizaciji, ali i osobina pojedinca. Povećanom riziku profesionalnog stresa (uz posljedični razvoj sindroma izgaranja i obolijevanja od psihosomatskih bolesti) uvelike pridonose visoka razina odgovornosti prema ljudskom životu i zdravlju, kontakt s oboljelima i njihovim obiteljima, odgovornost pri donošenju odluka, emocionalno i fizičko iscrpljivanje, smjenski i noćni rad te produljeno radno vrijeme. Unutar zdravstva također postoje manje i više stresna radna mjesta, a među ona više stresna ubrajaju se rad u psihijatrijskim jedinicama intenzivne skrbi i u hitnoj medicinskoj pomoći na koje se stavilo težište u ovome istraživanju.

Ovo istraživanje provedeno je s namjerom da se ustanovi postojanje uzroka profesionalnog stresa (stresori) i sindroma izgaranja u zdravstvenih djelatnika koji su zaposleni u intenzivnoj psihijatrijskoj skrbi Klinike za psihijatriju Vrapče i Nastavnom zavodu za hitnu medicinu Grada Zagreba.

Zdravstveni djelatnici zaposleni u hitnoj medicinskoj službi kontinuirano su izloženi specifičnom stresoru, a to je rad u izvanbolničkim uvjetima koji zahtijeva brzinu reagiranja i donošenja odluka, stručnost, snalažljivost i visoku razinu samostalnosti. Svakodnevno susretanje s nesrećama, traumama i tragedijama osoba kojima se pruža hitna medicinska pomoć može još dodatno potencirati traumatski aspekt suočavanja sa stresogenim situacijama uz razvoj kriznih stanja pa čak i posttraumatskog stresnog poremećaja. Istraživanje provedeno u Egiptu (Khashaba et al., 2014.) pokazalo je da su medicinski tehničari i vozači zaposleni u hitnoj medicinskoj pomoći bili više izloženi i akutnim i kroničnim profesionalnim stresorima te su imali povišenu razinu emocionalne iscrpljenosti, depersonalizacije i posttraumatskog stresnog poremećaja (u odnosu na komparativnu skupinu). Rezultati ovog rada pokazuju da je ukupni broj ispitanika ocijenio kategorije Organizacija radnog mjesta i financijska pitanja $(P=0,04)$, Opasnosti $i$ štetnosti na poslu $(P=0,46)$,
Smjenski rad $(P=0,046)$ kao najznačajnije stresore na svojim radnim mjestima. U kategorijama koje nisu statistički značajne ipak postoje određene čestice gdje postoje statistički značajne razlike, i to u kategoriji Javna kritika i sudske tužbe te čestici Pogrešno informiranje bolesnika od strane medija i drugih izvora $(P=0,049)$. Slično istraživanje (Strapajević, 2014.) pokazalo je kako se također većina ispitanika žali na preopterećenost poslom, nedostatan broj djelatnika, lošu organizacija posla, neadekvatna materijalna sredstva za rad te noćni rad.

Kod procjene psihofizioloških napora uočena je statistički značajna razlika u kategoriji „Pritisak na poslu“, u česticama "Istovremeno moram obavljati nekoliko poslova" $(P=0,000)$ i "Imam previše papirologije na svom poslu“ $(P=0,000)$. $U$ kategoriji "Stres uzrokovan premalim radnim opterećenjem" nađena je statistički značajna razlika u česticama „Previše sam kvalificiran za posao koji obavljam" $(P=0,008)$ te "Mala je šansa za napredovanje" $(P=0,005)$. U kategorijama koje se nisu pokazale statistički značajne ipak postoje određene čestice gdje se uočava statistički značajna razlika između djelatnika Nastavnog zavoda za hitnu medicinu grada Zagreb i djelatnika Intenzivne psihijatrijske skrbi Klinike za psihijatriju Vrapče. Tako na primjer u kategoriji „Zabrinutost za zdravlje u vezi s radom" - čestica "Obavljanje teških fizičkih poslova na neprimjereni način“ te kategoriji "Dosada na poslu" - čestica "Posao mi je prelagan" uočena je statistički značajna razlika djelatnika Hitne $(P=0,019 ; P=0,023)$. U kategorijama "Nesigurnost posla" - čestica "Zabrinut za egzistenciju zbog male plaće" i "Vremenski rokovi/pritisci" čestica "Stalno me podsjećaju na rokove u kojima moram završiti poslove" uočena je statistički značajna razlika u djelatnika Vrapče $(P=0,043$; $P=0,042)$. Istraživanje provedeno u Velikoj Britaniji (Health and Safety Executive, 2019.) pokazalo je da 602.000 radnika pate od stresa, depresije i anksioznosti povezanih s poslom (od toga je kod $44 \%$ uzrok preopterećenost, kod $14 \%$ manjak podrške, kod $13 \%$ nasilje, prijetnje ili maltretiranje, kod $8 \%$ promjene na poslu, a kod $21 \%$ su ostali uzroci), a čak 12,8 milijuna dana bolovanja bilo je povezano s radnim stresom. Zanimanja koja pokazuju veću razinu stresa (u usporedbi sa svim poslovima) su ona u javnoj službi - poglavito zdravstveni djelatnici, socijalni radnici, nastav- 
nici te zaposleni u državnoj administraciji i obrani (Health and Safety Executive, 2019.).

Rezultati dobiveni uporabom Upitnika sindroma sagorijevanja ukazuju na to da su glavni uzroci sindroma izgaranja sljedeći: „Osjećam se nemoćnim da promijenim nešto na poslu" (46 \% djelatnika Hitne i $32 \%$ djelatnika Vrapča), "Na poslu se osjećam umorno i iscrpljeno, čak i kad se dobro naspavam" (25\% djelatnika Hitne), „Posao veoma zamoran i rutinski“ (22\% djelatnika Vrapča).

Kod procjene sindroma izgaranja 40 ispitanika $(31,7 \%)$ bilo je bez sindroma izgaranja, početno izgaranje pokazalo je 53 ispitanika (42,1 \%), a visok stupanj izgaranja nađen je kod 33 ispitanika $(26,2 \%)$. Istraživanje koje je provedeno na djelatnicima KBC Zagreb, a kojim se ispitivala prisutnost sindroma izgaranja (Šmaguc, 2016.) pokazalo je da $49 \%$ ispitanika ne pokazuje sindrom izgaranja, 32 \% ispitanika ima početno izgaranje dok $19 \%$ ima visok stupanj izgaranja, što ne korespondira s rezultatima dobivenima ovim istraživanjem. Naime, ovo istraživanje ukazalo je na znatno veći broj djelatnika Hitne i Vrapča koji prijavljuju visok stupanj izgaranja za razliku od istraživanja u KBC Zagreb. To je vrlo vjerojatno u skladu s izloženošću stresorima okoline, gdje su djelatnici Hitne i Vrapča njima izloženi, zbog opisa radnog mjesta, svakodnevno. Naime, obje skupine ispitanika ovoga istraživanja često riskiraju svoje zdravlje i sigurnost, pogotovo u zbrinjavanju agresivnih i suicidalnih osoba.

\section{ZAKLJUČAK}

Djelatnici intenzivne psihijatrijske skrbi i hitne medicine su, zbog prirode i opsega posla koji rade, trajno izloženi izvorima stresa i psihofiziološkim naporima koji mogu rezultirati razvojem sindroma izgaranja pa čak i posttraumatskim stresnim poremećajem. To ne utječe samo na pojedinca, nego i na cijeli kolektiv, ali i kvalitetu pružene zdravstvene usluge. Trebalo bi provoditi sustavne programe prevencije i pomoći kod profesionalnog stresa kroz stvaranje podržavajuće, empatične i pozitivno anticipirajuće radne okoline, edukaciju djelatnika o suočavanju sa stresorima te pružanje psihološke pomoći djelatnicima kod kojih je profesionalni stres već ostavio posljedice. 
Prilog 1. Upitnik o sociodemografskim karakteristikama ispitanika

Opći podaci

1. DOB: u godinama:

2. SPOL: $M \quad$ Ž

3. ZAVRŠENA STRUČNA SPREMA: SS VŠS VSS

4. BRAČNO STANJE: $\square$ Živim s partnerom $\square$ Ne živim s partnerom

5. BROJ DJECE:

6. RADNO MJESTO:

\section{UKUPNI RADNI STAŽ u godinama:}

7a. Jeste li sezonski zaposlenik/zaposlenica?

$\square \mathrm{Da} \quad \square \mathrm{Ne}$

8. Koliko prosječno sati radite tjedno:

9. Jeste li u zadnjih godinu dana koristili bolovanje?

$\square \mathrm{Da} \quad \square \mathrm{Ne}$

9a. Ako da, koliko ste bili na bolovanju (upišite broj dana):

9b. Ako ste koristili bolovanje, koja Vam je bila dijagnoza: 
Prilog 2. Stres na radnom mjestu bolničkih zdravstvenih djelatnika

\section{Stres na radnom mjestu bolničkih zdravstvenih djelatnika}

Molimo Vas da pomoću slijedeće ljestvice prepoznate i ocijenite čimbenike stresa na svom radnom mjestu.

\begin{tabular}{c|c|c|c|cc} 
& $\mathbf{1}$ & $\mathbf{2}$ & $\mathbf{3}$ & $\mathbf{4}$ & $\mathbf{5}$ \\
\cline { 2 - 5 } & $\begin{array}{c}\text { Nije uopće } \\
\text { stresno }\end{array}$ & $\begin{array}{c}\text { Rijetko je } \\
\text { stresno }\end{array}$ & $\begin{array}{c}\text { Ponekad } \\
\text { stresno }\end{array}$ & Stresno & $\begin{array}{c}\text { Izrazito } \\
\text { stresno }\end{array}$
\end{tabular}

Pretpostavite da neki čimbenik, koji izaziva najviši stres koji ste doživjeli na svom radnom

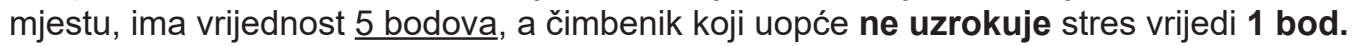

\section{Koliko bodova biste dali slijedećim čimbenicima na svom radnom mjestu?}

\begin{tabular}{|c|c|c|c|c|c|c|}
\hline 1. & Neadekvatna osobna primanja & 1 & 2 & 3 & 4 & 5 \\
\hline 2. & Neadekvatna materijalna sredstva za primjeren rad (financijska ograničenja) & 1 & 2 & 3 & 4 & 5 \\
\hline 3. & Neadekvatan radni prostor & 1 & 2 & 3 & 4 & 5 \\
\hline 4. & Mala mogućnost napredovanja & 1 & 2 & 3 & 4 & 5 \\
\hline 5. & Oskudna komunikacija s nadređenima & 1 & 2 & 3 & 4 & 5 \\
\hline 6. & Nedostatan broj djelatnika & 1 & 2 & 3 & 4 & 5 \\
\hline 7. & Loša ogranizacija posla & 1 & 2 & 3 & 4 & 5 \\
\hline 8. & Svakodnevne nepredviđene situacije & 1 & 2 & 3 & 4 & 5 \\
\hline 9. & Administrativni poslovi & 1 & 2 & 3 & 4 & 5 \\
\hline 10. & Preopterećenost poslom & 1 & 2 & 3 & 4 & 5 \\
\hline 11. & Prijetnja sudske tužbe i/lii parničenja & 1 & 2 & 3 & 4 & 5 \\
\hline 12. & Neadekvatna očekivanja od strane bolesnika i obitelji & 1 & 2 & 3 & 4 & 5 \\
\hline 13. & Izloženost neprimjerenoj javnoj kritici & 1 & 2 & 3 & 4 & 5 \\
\hline 14. & Pogrešno informiranje bolesnika od strane medija i drugih izvora & 1 & 2 & 3 & 4 & 5 \\
\hline 15. & Sukobi s bolesnikom ili članovima obitelji bolesnika & 1 & 2 & 3 & 4 & 5 \\
\hline 16. & Nemogućnost odvajanja profesionalnog i privatnog života & 1 & 2 & 3 & 4 & 5 \\
\hline 17. & 24-satna odgovornost & 1 & 2 & 3 & 4 & 5 \\
\hline
\end{tabular}

Upitnik o stresorima na radnom mjestu bolničkih zdravstvenih djelatnika v.2.0.

Sva prava pridržana, Škola narodnog zdravlja "Andrija Štampar", Medicinski fakultet Sveučilišta u Zagrebu 


\begin{tabular}{|c|c|c|c|c|c|c|}
\hline 18. & Strah od izloženosti ionizacijskom zračenju & 1 & 2 & 3 & 4 & 5 \\
\hline 19. & Strah zbog izloženosti inhalacijskim anesteticima & 1 & 2 & 3 & 4 & 5 \\
\hline 20. & Strah zbog izloženosti citostaticima & 1 & 2 & 3 & 4 & 5 \\
\hline 21. & Strah zbog mogućnosti zaraze & 1 & 2 & 3 & 4 & 5 \\
\hline 22. & Strah zbog mogućnosti ozljede oštrim predmetom & 1 & 2 & 3 & 4 & 5 \\
\hline 23. & Suočavanje s neizlječivim bolesnicima & 1 & 2 & 3 & 4 & 5 \\
\hline 24. & Sukobi s kolegama & 1 & 2 & 3 & 4 & 5 \\
\hline 25. & Sukobi s drugim suradnicima & 1 & 2 & 3 & 4 & 5 \\
\hline 26. & Oskudna komunikacija s kolegama & 1 & 2 & 3 & 4 & 5 \\
\hline 27. & Sukobi s nadređenim & 1 & 2 & 3 & 4 & 5 \\
\hline 28. & Noćni rad & 1 & 2 & 3 & 4 & 5 \\
\hline 29. & Smjenski rad & 1 & 2 & 3 & 4 & 5 \\
\hline 30. & Prekovremeni rad & 1 & 2 & 3 & 4 & 5 \\
\hline 31. & Dežurstva (24 sata) & 1 & 2 & 3 & 4 & 5 \\
\hline 32. & Uvođenje novih tehnologija & 1 & 2 & 3 & 4 & 5 \\
\hline 33. & "Bombardiranje" novim informacijama iz struke & 1 & 2 & 3 & 4 & 5 \\
\hline 34. & Nedostatak odgovarajuće trajne edukacije & 1 & 2 & 3 & 4 & 5 \\
\hline 35. & Nedostupnost potrebne literature & 1 & 2 & 3 & 4 & 5 \\
\hline 36. & Pritisak vremenskih rokova za izvršenje zadataka & 1 & 2 & 3 & 4 & 5 \\
\hline 37. & Vremensko ograničenje za pregled pacijenata & 1 & 2 & 3 & 4 & 5 \\
\hline
\end{tabular}


Prilog 3. Upitnik za procjenu psihofizioloških napora na radnom mjestu

\section{Upitnik za procjenu psihofizioloških napora na radnom mjestu}

Stresori na radu se mogu identificirati/naći u gotovo svim segmentima nečijeg rada. Određivanje izvora stresa na nekom poslu prvi je i nezaobilazan korak za planiranje aktivnosti sprečavanja doživljaja stresa te ublažavanja njegovih posljedica na radnu dobrobit i radno ponašanje. Za tu svrhu, podaci se mogu prikupiti primjenom ovog upitnika.

Uputa: Razmislite koliko se često susrećete sa sljedećim situacijama te svoje procjene zabilježite na skali od 1 do 5 .

Pritom ocjene imaju sljedeće značenje:

$1=$ Nikad

$2=$ Rijetko

$3=$ Povremeno

4 = Često

$5=$ Uvijek

\begin{tabular}{|l|l|}
\hline \multicolumn{1}{|c|}{ A. Neslaganje i neodlučnost na poslu } & Ocjena \\
\hline Nisam siguran što kolege od mene očekuju & \\
\hline Kolege na poslu imaju negativan odnos prema meni & \\
\hline $\begin{array}{l}\text { Ne slažem se s uputama poslodavca o načinu na koji trebam obavljati } \\
\text { zadane poslove }\end{array}$ & \\
\hline Ne mogu ispuniti proturječne zahtjeve svojih nadređenih za pojedini posao & \\
\hline Imam problema kad odbijam raditi prekovremeno & \\
\hline
\end{tabular}

\begin{tabular}{|l|l|}
\hline \multicolumn{1}{|c|}{ B. Pritisak na poslu } & Ocjena \\
\hline Istovremeno moram obavljati nekoliko poslova & \\
\hline Nadređeni me previše kontroliraju pri obavljanju poslova & \\
\hline Moj posao previše utječe na moj privatni život & \\
\hline Obavljam poslove koji se moraju obaviti na brzinu & \\
\hline Imam previše "papirologije" na svom poslu & \\
\hline
\end{tabular}




\begin{tabular}{|l|l|}
\hline \multicolumn{1}{|c|}{ C. Proturječnosti u obavljanju poslova } & Ocjena \\
\hline Nisam siguran/na što su moji radni zadaci i odgovornosti & \\
\hline Nameću mi previše timskog rada & \\
\hline Ne dobivam dovoljno informacija za uspješno obavljanje poslova & \\
\hline Nemam dovoljno ovlasti za uspješno izvršavanje radnih zadataka & \\
\hline $\begin{array}{l}\text { Osjećam nelagodu kada moram obavljati radne zadaće suprotno } \\
\text { uvjerenjima. }\end{array}$ & \\
\hline
\end{tabular}

\begin{tabular}{|l|l|}
\hline \multicolumn{1}{|c|}{ D. Komunikacija i podrška nadređenih } & Ocjena \\
\hline Moje ideje o načinu i provođenju poslova razlikuju se od ideja nadređenih & \\
\hline Nemam priliku razgovarati s nadređenima & \\
\hline Ne mogu predvidjeti reakcije svojih nadređenih & \\
\hline $\begin{array}{l}\text { Nadređeni mi daje premalo povratnih informacija o tome kako obavljam } \\
\text { svoje poslove }\end{array}$ & \\
\hline Nadređeni me previše kritizira & \\
\hline
\end{tabular}

\begin{tabular}{|l|l|}
\hline \multicolumn{1}{|c|}{ E. Zabrinutost za zdravlje u vezi s radom } & Ocjena \\
\hline Nedovoljna briga za zdravlje i sigurnost na radu & \\
\hline Povećan je rizik od fizikalnih štetnosti, ali to nikoga ne brine & \\
\hline Obavljanje teških fizičkih poslova na neprimjeren način & \\
\hline Neugodne prijetnje kolega & \\
\hline Nepoželjno je ići na bolovanje & \\
\hline
\end{tabular}




\begin{tabular}{|l|l|}
\hline \multicolumn{1}{|c|}{ F. Preveliko radno opterećenje } & Ocjena \\
\hline Ne stižem se savjetovati s kolegama & \\
\hline Kolege su neučinkoviti & \\
\hline Često nosim posao kući & \\
\hline Odgovoran sam za preveliki broj ljudi i radnih zadataka & \\
\hline Nemam pomoć kad mi zatreba & \\
\hline
\end{tabular}

\begin{tabular}{|l|l|}
\hline \multicolumn{1}{|c|}{ G. Premalo radno opterećenje } & Ocjena \\
\hline Imam premalo odgovornosti na poslu & \\
\hline Previše sam kvalificiran za posao koji obavljam & \\
\hline Mala je šansa za napredovanjem & \\
\hline Trudim se "djelovati" zaposleno & \\
\hline Nisam potican raditi više & \\
\hline
\end{tabular}

\begin{tabular}{|l|l|}
\hline \multicolumn{1}{|c|}{ H. Dosada na poslu } & Ocjena \\
\hline Radim samo ponavljajuće i izrazito rutinske poslove & \\
\hline Ne učim ništa novo na poslu & \\
\hline Ne vidim krajnji rezultat svojega truda & \\
\hline Posao mi je prelagan & \\
\hline Često sanjarim na poslu & \\
\hline
\end{tabular}




\begin{tabular}{|l|l|}
\hline \multicolumn{1}{|c|}{ I. Nesigurnost posla } & Ocjena \\
\hline Bojim se da ću dobiti otkaz & \\
\hline Brinem zbog niske mirovine & \\
\hline Zabrinut za egzistenciju zbog male plaće & \\
\hline Kod mog poslodavca je za napredovanje potrebna veza & \\
\hline Bojim se otkaza bez opravdanog razloga & \\
\hline
\end{tabular}

\begin{tabular}{|l|l|}
\hline \multicolumn{1}{|c|}{ J. Vremenski rokovi/pritisci } & Ocjena \\
\hline Stalno me podsjećaju na rokove u kojima moram završiti poslove & \\
\hline Radno vrijeme je fiksno pa ne mogu završiti poslove & \\
\hline Zbog jednoličnog posla često kasnim s rokovima & \\
\hline Nema dovoljno pauza za odmor ili obrok & \\
\hline Ritam rada je prebrz & \\
\hline
\end{tabular}

\begin{tabular}{|l|l|}
\hline \multicolumn{1}{|c|}{ K. Zapreke na poslu } & Ocjena \\
\hline Ograničena je mogućnost za napredovanje i povišicu & \\
\hline Na poslu postoji spolna/dobna diskriminacija & \\
\hline $\begin{array}{l}\text { Nisam prikladan za posao koji obavljam (Školska sprema, radne vještine, } \\
\text { fizičke i psihičke karakteristike) }\end{array}$ & \\
\hline Posao mi osobno ništa ne znači & \\
\hline Moj posao ostaje nezapažen & \\
\hline
\end{tabular}




\section{LITERATURA}

Ajduković, D.: Izvori profesionalnog stresa i sagorijevanja pomagača. U: Ajdković, D., Ajduković, M. (Ur.): Pomoć i samopomoć u skrbi za mentalno zdravlje pomagača. Društvo za psihološku pomoć, Zagreb, 1996., str. 29-37.

Alexander, DA.: Normal and pathological reactions to severe stress: their features and management. J R Army Med Corps. 146, 2000., 3, 165-70.

Cooper, CL., Sloan, SJ., Williams, S.: Occupational stress indicator. Management guide. Windsor: NFER-Nelson, 1988.

Cuculić, A.: Stres i burn-out sindrom kod djelatnika penalnih institucija. Krimatologija i socijalna integracija: časopis za kriminologiju, penologiju i poremećaje u ponašanju, 14, 2006., 2, 61-78.

Gray-Toft, P., Anderson, JG.: Stress among hospital nursing staff: its causes and effects. SOC Sci Med, 15, 1981., 639-647.

Havelka, M.: Stres i tjelesno zdravlje. U: Havelka, M. (Ur.): Zdravstvena psihologija. Naklada Slap, Jastrebarsko, 1998., str. 53-88.

Health and Safety Executive. Work-related stress, anxiety or depression statistics in Great Britain, 2019., dostupno na: https://www.hse. gov.uk/statistics/causdis/stress.pdf. Pristupljeno: 30.12. 2019.

Horowitz, M.: Stress Response Syndromes. $2^{\text {nd }}$ Edition. Jason Aronson Inc, New York, 1978.

Hudek-Knežević, J., Kardum, I.: Stres i tjelesno zdravlje. Naklada Slap, Jastrebarsko, 2006., str. 13-32.

Khashaba, EO., El-Sherif, MA., Ibrahim, AA., Neatmatallah, MA.: Work-Related Psychosocial Hazards Among Emergency Medical Responders (EMRs) in Mansoura City. Indian J Community Med. 39, 2014., 2, 103-110.
Martin, F., Poyen, D., Bouderlique, E., Gouvernet, J., Rivet, B., Disdier, P., Martinez, O., Scotto, JC.: Depression and Burnout in Hospital Health Care Professionals. Int J Occup Environ Health. 3, 1997., 3, 204-209.

Milošević, M.: Izrada mjernog instrumenta stresa na radnom mjestu bolničkih zdravstvenih djelatnika i procjena njegove uporabne vrijednosti. Disertacija. Medicinski fakultet Sveučilišta u Zagrebu, Zagreb, 2010.

Murray, E., Krahé, C., Goodsman, D.: Are medical students in prehospital care at risk of moral injury? Emerg Med J. 2018., doi: 10.1136/emermed-2017-207216.

Pavičević, L., Bobić, J.: Stres na radu. U: Šarić M, Žuškin E (Ur.): Medicina rada i okoliša. Medicinska naklada, Zagreb, 2002., str. 530-537.

Raphael, B., Meldrum, L.: Does debriefing after psychological trauma work? BMJ. 310, 1995. 6993, 1479-1480.

Sambol, D.: Stresni traumatski događaji i njihove posljedice. Narodni zdravstveni list, 2009., dostupno na: http://www.zzjzpgz.hr/nzl/57/kadvise-ne-mogu.htm. Pristupljeno: 25.8.2018.

Sauter, S.: Stress at Work. DHHS (NIOSH). Publication, 1999., 99-101, dostupno na: http:// www.cdc.gov/niosh/docs/99-101/pdfs/99-101. pdf. Pristupljeno: 25.8.2018.

Skala profesionalnog stresa, dostupno na: http://hzzzsr.hr/wp-content/uploads/2016/12/ HSE_dodana-skala-1.pdf. Pristupljeno: 21.5.2018.

Strapajević, D.: Procjena utjecaja rada u integriranoj bolničkoj hitnoj službi na zdravlje i radnu sposobnost djelatnika. Diplomski rad. Medicinski fakultet Sveučilišta u Zagrebu Zagreb, 2014.

Škrinjar, J.: Profesionalna opterećenost $i$ sindrom burnout djelatnika u ustanovama za rehabilitaciju osoba s težom mentalnom retardacijom. Disertacija. Fakultet za defektologiju Sveučilišta u Zagrebu, Zagreb, 1994. 


\section{PROFESSIONAL STRESS AND BURNOUT SYNDROME IN INTENSIVE PSYCHIATRIC CARE AND EMERGENCY MEDICINE EMPLOYEES}

SUMMARY: In the last decades professional stress taking the form of physical, psychological and social response has been investigated. The dysfunction caused by stress rests on a person's feeling that workplace demands cannot be fulfilled as expected. This is due to a series of factors: overwhelming workload, inadequate job organization, poor communication, and overall work environment. Burnout syndrome occurs as a result of multiple stressors in the workplace and long-term exposure to them. The aim of this study was to investigate the presence and intensity of professional stress and burnout syndrome in intensive psychiatric care and emergency medicine employees. The factors of psychophysiological work-related strains and their relation to higher intensity of stress and burnout syndrome in participants were explored. The survey included 63 intensive psychiatric care employees at the University Psychiatric Hospital Vrapče and 63 employees at the Institute of Emergency Medicine Zagreb. Three standardized self-assessment questionnaires were used. The results obtained by analyzing workplace stress highlight stressor category "Workplace organization and financial issues". In this particular category $70 \%(\mathrm{~N}=88)$ of all participants believe that the stressor called "Excessive work" is a dominant source of stress ( $p=0.004)$. In assessing psychophysiological work-related strains, a statistically significant difference was found in the category "Pressure at work" $(p=0.001)$ and "Stress caused by low workload" ( $p=0.004)$. In the evaluation of the burnout syndrome, $31.7 \%(\mathrm{~N}=40)$ of all participants was found without syndrome. Initial burnout was found in $42.1 \%(\mathrm{~N}=53)$ of all participants, and $26.2 \%(\mathrm{~N}=33)$ of all participants showed a high degree of burnout. The results indicate the necessity of developing systematic programs for the prevention of professional stress with appropriate measures to improve working conditions in certain institutions.

Key words: emergency medicine, intensive psychiatric care, medical workers, professional stress, burnout syndrome

Original scientific paper

Received: 2020-01-08

Accepted: 2020-08-31 